\title{
EXPORTING CANADIAN IMMIGRATION POLICY: A COMPARATIVE ANALYSIS OF PRIVATE SPONSORSHIP METHODS IN CANADA, THE U.K, AND GERMANY
}

$$
\text { by }
$$

Shaina Bianca Somers, BA, University of British Columbia, 2016.

\author{
A Major Research Paper \\ presented to Ryerson University \\ in partial fulfillment of the requirements for the degree of \\ Master of Arts \\ in the Program of \\ Immigration and Settlement Studies
}

Toronto, Ontario, Canada

(C) Shaina Bianca Somers, 2019 


\section{AUTHOR'S DECLARATION FOR AN ELECTRONIC SUBMISSION OF AN MRP}

I hereby declare that I am the sole author of this MRP. This is a true copy of the MRP, including any required final revisions.

I authorize Ryerson University to lend this MRP to other institutions or individuals for the purpose of scholarly research.

I further authorize Ryerson University to reproduce this MRP by photocopying or by other means, in total or in part, at the request of other institutions or individuals for the purpose of scholarly research.

I understand that my MRP may be made electronically available to the public.

Shaina Bianca Somers 


\title{
EXPORTING CANADIAN IMMIGRATION POLICY: A COMPARATIVE ANALYSIS OF PRIVATE SPONSORSHIP METHODS IN CANADA, THE U.K, AND GERMANY
}

\section{Shaina Bianca Somers}

Master of Arts, 2019

\section{Immigration and Settlement Studies}

\section{Ryerson University}

\begin{abstract}
The private sponsorship of refugees (PSR) model, created in Canada 40 years ago, has a structure which allows citizens and permanent residents concerned about refugee resettlement to take action in their local communities by sponsoring refugees and providing them with financial, social and integration support. This paper critically analyzes and compares the private sponsorship of refugees (PSR) model in Canada, the United Kingdom (U.K.) and Germany and how it is being promoted, portrayed and received in each country. I argue that the PSR model should be a refugee resettlement option provided that the number of refugees admitted through this stream should not surpass the number of refugees admitted through government sponsorship; effective oversight and evaluation should be administered by governments and NGOs over groups and communities involved in sponsorship; and, diverse images and perspectives of refugees themselves should be used in the promotional material from governments and NGOs about private sponsorship.
\end{abstract}

Key words: Canada, United Kingdom, Germany, private sponsorship, refugee, immigration policy, refugee resettlement 


\section{ACKNOWLEDGEMENTS}

To my loved ones who encouraged me to pursue my goals and passion in this field, thank you. You have done so much more for me than you know. My grandparents especially, whose sacrifices and stories of migration I hold close to my heart, thank you for everything.

My sincerest thanks to Dr. John Shields for being an attentive advisor and patient supervisor, and Dr. Bryan Evans for acting as my second reader. I also thank Dr. Myer Siemiatycki for his encouragement during the Immigration and Settlement Studies program, and Dr. Mehrunnisa Ali for her guidance.

I would also like to express my gratitude to Focus Migration at the Institute of Migration and Intercultural Studies (IMIS) and the International Migration \& Intercultural Relations (IMIB) MA program at the Universität Osnabrück in Osnabrück, Germany. The students, staff and faculty were very generous in their hospitality and support during the writing of this MRP and provided exceptional insight into the German immigration system.

Lastly, thank you to Mitacs Canada for their financial support to complete this research in Germany and Canada. 


\section{DEDICATION}

This MRP is dedicated to the families, communities and citizens who dedicate their time and resources to private sponsorship initiatives and to those that come to Canada through this pathway. Your perseverance, patience, empathy and hard work is recognized and valued. 


\section{TABLE OF CONTENTS}

DECLARATION FOR ELECTRONIC SUBMISSION OF AN MRP....................ii

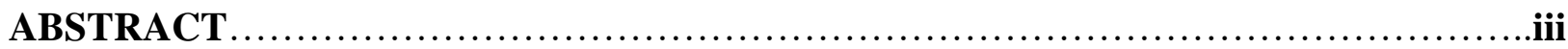

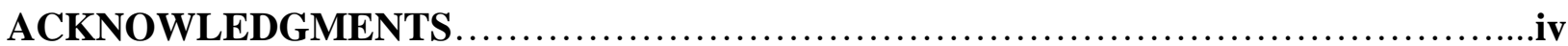

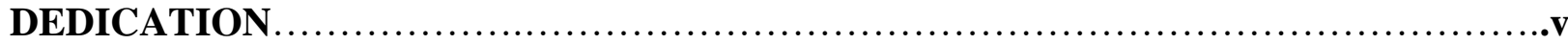

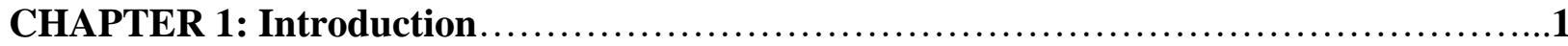

CHAPTER 2: Theoretical and Conceptual Frameworks...............................6

Neoliberalism ...................................................................

Localism........................................................................ 8

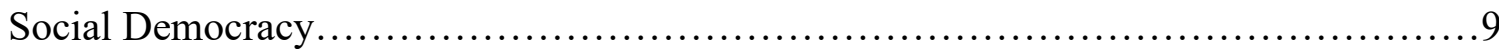

CHAPTER 3: Research Rationale and Approach....................................... 12

Research Question.........................................................12

Operational Definition: Defining 'Success' .....................................12

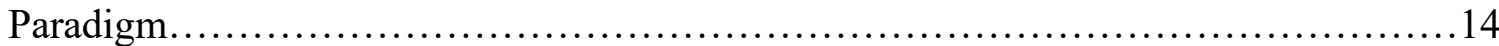

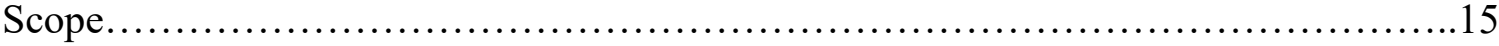

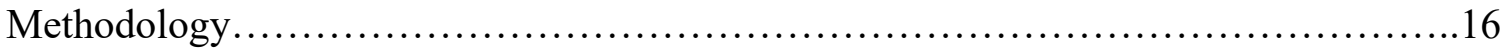

Data Collection............................................................ 19

Researcher Self Disclosure ................................................... 20

CHAPTER 4: 40 Years in the Making: Canada's PSR Program.............................23

History of Private Sponsorship of Refugees Program..............................23

Government Assisted Refugees................................................28

Development of the PSR Program.............................................29

Critiques of the Canadian Private Sponsorship of Refugees Program.................. 31

CHAPTER 5: Community Sponsorship in the United Kingdom.......................36

Forming Community Sponsorship Policy in the United Kingdom......................36

Localism and Community Sponsorship ....................................... 38

CHAPTER 6: Emerging Private Sponsorship in Germany $\ldots . . \ldots \ldots \ldots \ldots \ldots \ldots \ldots \ldots \ldots \ldots \ldots \ldots . . . . .41$

2015: First Responses........................................................ 41

Changes, Developments and Going Forward....................................42 
Social Democracy and Private Sponsorship in Germany.

CHAPTER 7: Promotion and Reception of PSR..............................................44

Ordinary people becoming extraordinary......................................44

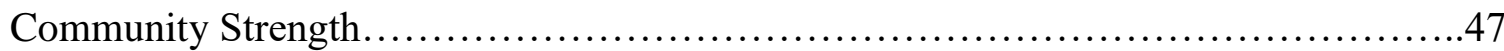

Families: First and Foremost.............................................. 49

CHAPTER 8: Conclusion................................................................50

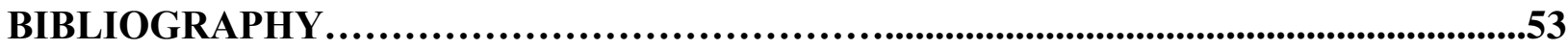




\section{CHAPTER One}

\section{Introduction}

Recent years have seen immigration become one of the most widely discussed political issues in global politics. The dangerous risks that people take to flee their countries of origin and the ongoing debate over best practices for refugee settlement and integration are some of the most pressing concerns and policy considerations facing European countries today. The United Nations High Commission for Refugees (UNHCR) has urged governments in Europe to make fundamental changes to their refugee resettlement programs in order to provide safe and orderly passage for immigration into Europe (Kumin, 2015). Currently less than $1 \%$ of the world's refugee population is able to benefit from existing long-term resettlement programs (Global Refugee Sponsorship Initiative (GRSI) Fact Sheet, 2016). The Global Compact for Safe, Orderly and Regular Migration signed in Morocco in December 2018 has called for more countries around the world to allow for increased means and methods of regular migration as a collective effort to minimize the risks that vulnerable groups like refugees take to reach safety (Global Compact on Migration, 2018).

Implementing a Canadian style private sponsorship of refugees model organized and led by civil society has been identified by governments and local communities in Europe, South America and Oceania as an option to increase successful and sustaintainable refugee resettlement (International Catholic Migration Commission, 2017; Kumin, 2015; GRSI, 2016; Government of the United Kingdom, 2018). This model has garnered interest from various private bodies as its structure allows citizens and permanent residents concerned about refugee resettlement to take action in their local communities by sponsoring refugees and providing them with financial, 
social and integration support. Sponsors assist individuals or groups with daily living necessities, such as securing housing, finding employment, hosting language classes and other financial obligations for a total of twelve months (IRCC, 2019).

Canada's model of private sponsorship of refugees (hereafter "PSR") remains the longest running example of its kind (Kumin, 2015; European Commission, 2018; GRSI 2016; Salono \& Savazzi, 2019). Its forty-year history affords Canada the long term position of being considered a leader in this field by numerous other countries who have adopted it to varying degrees since. Governments, civil society and communities around the world are becoming increasingly interested in developing a similar PSR policy as large global population movements require more long-term resettlement options for a greater number of refugees (GRSI 2016; Harris, 2016). Canada's 'unique' model is being studied purposefully and with serious intent by stakeholders who wish to consider more innovative approaches to refugee integration in their own communities and to invest time and money into more options for resettlement.

The PSR model was added to Canada's immigration policy in 1976. It was a popular and effective measure utilized by Canadian civil society as a tool to accept, resettle and integrate tens of thousands of Southeast Asian refugees fleeing conflict in Vietnam, Cambodia and Laos (Molloy and Simeon, 2016). Although the Syrian refugee crisis has drawn the PSR model back into the spotlight, since the 1970's it has continued in operation with additions and modifications over the years. Some of the literature suggests that refugees who have been privately sponsored are considered to be more 'successful' (Dhital, 2015; Neuwirth \& Clarke, 1981, as cited in Ugland, 2018) than government assisted refugees, or refugees who are deemed admissible to Canada after making asylum claims at official or unofficial border crossings. Refugees who enter through these pathways may not have ready access to resources and support upon arrival in 
Canada in comparison to those who come through the PSR model.

However, it is important to consider how PSR is being promoted and advertised by governments, NGOs and the news media in relation to how it is working in practice. Before Canada touts this model as a positive example that other countries can learn from, it is useful to question whether community based private sponsorship really is the best model for refugee resettlement and integration (Ireland, 2016; Lenard, 2016; Ritchie, 2018; Smith et al., 2017) Does private sponsorship truly result in more successful integration and support for refugees? Furthermore, can it be an effective response to the global refugee crisis and the challenges other countries are facing?

This paper will be principally concerned with United Kingdom (U.K) and German policy in the area and how it compares to that of Canada in order to critically analyze how private sponsorship is being promoted, portrayed and received in each country. The U.K and Germany are countries in which private sponsorship is a relatively recent endeavor in the landscape of refugee resettlement policy. In 2013, no private sponsorship initiatives existed in Europe and in 2015 the U.K was not even on the list of European countries that had a PSR program (Kumin, 2015). The U.K has been operating and promoting a community sponsorship scheme for refugees since July 2016 (Citizens UK, 2019). In May 2019, Germany launched its pilot community sponsorship program- NEST to sponsor 500 vulnerable refugees identified by UNHCR criteria (Federal Ministry of the Interior, Construction and Home, 2019). I am interested in examining the reception and success the Canadian private refugee sponsorship model is having in other countries as I argue it should be a refugee resettlement option available in other countries on a number of conditions. Firstly, the number of refugees admitted through PSR should not surpass numbers of refugees admitted through government sponsorship. Second, 
effective oversight and evaluation should be administered by governments and NGOs over groups and communities involved in sponsorship. Third, diverse images and perspectives of refugees themselves should be used in the promotional material from governments and NGOs about private sponsorship.

The private sponsorship promotional materials and news media in Canada and the U.K tend to focus on three main themes: ordinary citizens becoming extraordinary, community strength, and perhaps most crucially, family unification. To some extent these themes are prevalent in the German context but due to the recent nature of the country's official PSR program, the analysis is limited to government documents and news media available in English. Across the three countries, the promotional material does not usually include the perspectives of the refugees themselves, instead focusing more on the benefits that private sponsorship has within and for communities. Although in Canada, existing peer reviewed academic literature and news media provides more critical analysis of the PSR model than in the European context, this can be attributed to the policy's forty-year history in Canada. The length of time PSR has been in Canada makes it possible to reexamine, research and study its long-term effects. These effects include generally positive outcomes for privately sponsored refugees who tend to achieve faster labour market integration at the outset (Smith et al., 2007). However, other scholars in this field draw attention to a lack of monitoring and evaluation of sponsors and privately sponsored refugees (Salono \& Savazzi, 2019) which points to a need for more studies and research for both of these groups.

In the U.K, however, promotional material regarding private sponsorship still tends to focus on 'feel good' pieces and positive benefits of the community sponsorship model with limited critical analysis from other sources to provide additional perspectives. This may be 
because community sponsorship is still a relatively recent endeavor that is still gaining exposure and seeking public approval. It may be too soon to identify critiques of the U.K model, although there is emerging scholarly literature in this area (Phillimore \& Reyes, 2019), and for NGOs, governments and even academics to just critique the model would not assist with creating opportunities for more refugee resettlement.

A comparative analysis of countries and communities wishing to undertake a private sponsorship model to help address the global need for legal, safe and orderly pathways to migration will be useful to future scholars who wish to compare how private sponsorship models in different countries work to support refugees. This research will also be useful to policymakers who believe that a PSR model is an appropriate response to the ongoing refugee movements in Europe and that it is a sustainable method to compliment additional refugee resettlement policies going forward.

The purpose of this paper is to provide a critical review of the literature analyzing private refugee sponsorship models and its implications on sponsors, refugees and the communities involved. Chapter Two provides a discussion of theoretical frameworks of neoliberalism, localism and social democracy and they will be utilized as lenses to analyze PSR in the three country case studies. Chapter Three provides an outline of the research methods. The paper will then provide a literature review on past and current PSR initiatives and developments in Canada, the U.K and Germany. Although the paper's main focus is to provide an integrated literature review, a brief content analysis will be applied to materials promoting private refugee sponsorship in Canada and the U.K. and to a limited extent Germany, in an effort to provide an additional depth to understanding the promotion and reception of the PSR model within civil society. Finally, the paper will conclude with a summary of the key findings of the research. 


\section{CHAPTER 2}

\section{Theoretical and Conceptual Frameworks}

Theories of neoliberalism, localism and social democracy are best placed to examine how the conversation around private sponsorship refugee resettlement is framed in Canadian, British and German contexts. The choice to analyze each country through a different lens is to showcase and better highlight how the private sponsorship model is being received and how policy makers are responding to the model given the different historical, political and policy situations that exist in each of these places. However, as discussed in this chapter, these theories are not independent of one another. Some of the existing literature has used citizenship and theories of Kantian hospitality and sovereignty as a conceptual framework in understanding how private sponsorship affects sponsors and refugees, and why communities and private citizens choose to sponsor in the first place (Krivenko, 2012; Macklin et al, 2018).

In this paper, Canada's attitudes towards PSR will be interpreted under neoliberalism, the U.K.'s under localism, and Germany under social democracy. Neoliberal thought and policy in Canada highlights the increasing reliance on the PSR model over the years whilst localism allows us instead to see how PSR fits within the U.K.'s growing emphasis on community led actions to solve long term social issues (Soteri-Proctor et al, 2013). Although social democracy has been in decline in Germany, using it as a framework lends us the opportunity to regard how the PSR model works within this political theory that has a complicated relationship with issues of immigration in addition to historical significance in the country and Europe in general. 


\section{Neoliberalism}

Individual property rights, the rule of law, and free trade as well as free markets are crucial elements for individual freedoms. These ideas along with the ability for businesses and corporations to operate with limited restrictions are characteristics of neoliberal states (Harvey, 2007). The focus on the individual's responsibility for their own actions and wellbeing in terms of welfare, education, health care and pensions are key components in neoliberalism (Harvey, 2007). Neoliberal market principles and economic rationale have also seeped their way into social and cultural fabric of life (Gonzalez Benson, 2016) including immigration policy. AratKoc (1999) cautions that although refugee policies differ from standard immigration policy because of their political and historical significance, they too are subject to neoliberal policy. Neoliberal policies and thinking indeed have been influential on refugee policy and EastonCalabria \& Omata (2018) argue that the rhetoric of 'self-reliance' for refugees has grown more and more prominent as the ideal level of achievement for them. In the context of private sponsorship, self-reliance is certainly a goal for refugees and sponsors to work towards together. Increased belief that private sponsorship allows for this to be achieved quicker and sooner makes this model seem attractive, however it runs the risk of the government and other bodies withdrawing their monetary support or other forms of assistance.

Analyzing Canada's model of private refugee sponsorship through the lens of neoliberalism is prevalent in the existing academic literature. Ritchie is especially critical of the private sponsorship model for its downloading of costs from governments to private citizens and communities and states that: "the humanitarian act of privately resettling refugees simultaneously advances the class project of neoliberal restructuring” (Ritchie, 679, 2018). Lenard is also critical of the Canadian government's reliance on private sponsorship and believes 
that it is treated primarily as a cost-saving measure rather than a cost-sharing one (Lenard, 2016). It may appear that Canada embracing this model is an example of its preference for neoliberal policies over state control of refugee resettlement. In Canada, government assisted refugees are treated as a different category; their financial and social support comes from the government and settlement services rather than private citizens.

\section{Localism}

In conjunction with neoliberalism and social democracy, using localism as a conceptual framework can help identify the ways that actors in individual local communities are encouraged to support refugee resettlement. One of GRSI's main priorities is to, "strengthen local host communities that come together to welcome newcomers" (GRSI, 2018). The Citizens U.K. Foundation for the Sponsorship of Refugees established in October 2017 based on the Canadian model highlights the power of local communities. A feature story on their website is about how the small town of Hythe on the Kent coast came together to collectively organize themselves to be able to support a refugee family. A community member was interviewed and quoted as saying that even though they had not welcomed a family yet, the positive impact the private sponsorship effort has had on the community can already be felt (Feldman, 2019). In the U.K. the emphasis on the power of the local community is imperative to the success of the private sponsorship model. Localism aims to give substantial and sustained power to local people rather than have it be held exclusively by centralized governments.

Porteous (2013) defines localism as the "shift in power and resources away from centralized top-down government and decision-making structures to devolved democratic and collaborative community structures" (503). In the U.K. concepts of localism were apparent in the 
former Labour Party's administration and became enshrined in law with the Localism Act of 2011 passed under the coalition government and with the creation of a "decentralization team" in the Department for Communities and Local Government (Mills, 2012). Former Prime Minister David Cameron's "Big Society" initiative provided much of the early impetus behind the legislation. Big Society was meant to stand in contrast to the idea of the 'Big State' and social democracy. Although the focus on localism may be beneficial for communities to feel empowered to sponsor refugee families, it is important to note that the drive and interest in localism comes from the neoliberal downloading from the state level to the community level in the country.

\section{Social Democracy}

Social democracy prides itself on valuing a number of things such as freedom, equality, justice, solidarity, cooperation, community development (University of Manitoba, n.d; Kastning, 2013). Since Eduard Bernstein laid the groundwork for social democracy, it has been made to adapt to the permanence of globalisation and capitalism (Thompson, 2009) which tend to favour the neoliberal approach and rather than focusing on class struggles, highlight themes of working towards building community and shared values (Berman, 2014).

Social democracy has a somewhat complicated relationship with issues of immigration as their quest in championing labour rights and national self-determination can be at odds with immigration rights (Lacroix, 2016). This is particularly the case in Sweden with the Swedish Social Democratic Party (SAP) and its thriving policies of social democracy coupled with its restrictions on refugees and asylum seekers included or even admitted as part of the fabric of the nation (Schall, 2016; Hinnfors et al., 2012). The history of social democracy in Germany has 
seen the Social Democratic Party (SPD) of Germany modernizing its policies and platforms to shed itself of its Marxist values and work towards reforming capitalism rather than dismantling it (Berman, 2014). However, although SPD does govern in some state governments and has a partnership with the German federal parliament, by governing in coalition with the Union parties (ie. Christian Democratic Union of Germany (CDU) and Christian Social Union in Bavaria (CSU), social democracy has not been a driving force in German politics for a number of years.

Critics state that social democracy has declined, rather than adapted to respond to the rise of neoliberalism (Meyer \& Hitchman, 2017; Lavelle, 2008). With rising right wing populism, support for social democratic and other mainstream political parties have been lessening (Fekete, 2017). While Germany in particular has been very progressive in accepting a large number of refugees, issues of immigration played a critical role in the United Kingdom's referendum to leave the European Union (Powell, 2017). Corbett and Walker argue that since the Brexit vote in 2016, the European Union is increasingly going towards a neoliberal direction that contradicts the values of the European social model (Corbett \& Walker, 2019).

Nonetheless, social democracy still retains some presence in mainland Europe as compared to North America. Using social democracy as a framework to understand Germany's reception and support of the private sponsorship model is important because of its willingness and interest in the Canadian private sponsorship model may be understood as both a wish to support a socially democratic policy which lends itself to building and growing community and supporting rights and freedoms as refugees in addition to being regarded as a neoliberal project. A policy report released by Migration Policy Institute Europe affirms private sponsorship and regards it as a positive way to strengthen refugee resettlement in Europe (Kumin, 2015). Private sponsorship is seen as a way to resettle more refugees at a lower cost to the government, 
although this is qualified later in the report noting that governments should not cherry pick their privately sponsored refugees, or if they do so then complementary government assisted programs are required for those who need support as well (Kumin, 2015). Even though Germany's official pilot private sponsorship program was just launched, using social democracy as a lens to understand Germany's reception and promotion of the program illuminates the differences and similarities in the Canadian and British models. 


\section{CHAPTER 3}

\section{Research Rationale and Approach}

\section{Research Question}

This paper is chiefly concerned with the question of how, and to what extent, the Canadian model of private sponsorship for refugees (hereafter "PSR") has been promoted, received and implemented in other countries and communities. This in turn raises subsequent questions such as: are Germany and the United Kingdom using programs and policies from Canada, and if so, how are these ideas being adapted to fit the needs of the sponsored refugees and community sponsor groups? What are the similarities and challenges with PSR in Canada, the U.K and Germany? Finally, what can Canada learn about its own PSR model when it is adapted in other countries?

\section{Operational Definitions: Defining 'Success'}

Multiple aspects frame the guiding research questions. One must first examine how the PSR model has worked in Canada and subsequently how much success the Canadian template has been found to have when adapted by other countries. Does Canada's geo-political climate allow for the PSR model to thrive and thus, those who are privately sponsored become more 'successful' at entering the labour market and becoming integrated into Canadian society, over

refugees who come to Canada through government assistance or those who claim asylum? At a minimum, is 'success' considered having access to shelter, food, and a means of economic income? For the purposes of the policy in question and its aims success can be defined in this way. 
However, higher levels of social capital and increased social bonds with others can also be applicable indicators of success and integration (Silvius, 2016, GRSI, 2016; Ha \& Tyyskä, 2019). The status of being 'integrated' is also often used as a key measure of 'success' for immigrants and refugees. The U.K's Home Office uses work, education, health and social care, social bonds (shared sense of identity), social bridges (with people from different backgrounds), language and communication, digital skills, safety and stability as measures of successful integration (Home Office Indicators for Integration Framework, 2019).

Additionally, refugees' positive feelings of attachment and belonging to their new local communities, whether that is their neighborhood, city, schools or workplaces, are also important measures of success. Beiser's (2003) research argued that refugees who were privately sponsored were more likely to achieve long-term successful adaptation to Canada. His empirical ten-year study of 1,300 South East Asian refugees admitted in 1979-1981 during the 'boat people crisis' found that privately sponsored refugees measured higher in these values of success over government assisted refugees. Beiser (2003) used gainful employment, official language ability, and general health as measures of success.

It is important, however, to note that government assisted refugees also tend to have more specific needs when compared to privately sponsored refugees (Statistics Canada, 2019). Nevertheless, Cooper in his study states that operational definitions such as this must not be defined too narrowly or broadly as the "quality of findings can be impaired when other definitions are not considered" which "can lead to overlooking important study details and incorrectly interpreting results" (as cited in Russel, 2005, p.10). With this in mind, our definition of 'success' will not only consider the aforementioned studies but will also take account of the 
extensive body of academic work on the subject which has been written since. Consequently, 'success' is something to be constantly revisited by policy makers and academics alike.

\section{Paradigm}

A pragmatic paradigm provides a perspective on PSR that is oriented in real-world practice. This paper aims to be constructivist in nature with the use of a comparison of different PSR models in order to understand what is working and what can be improved upon. I intend to not only thoroughly investigate and critique PSR, but to provide guidance and address the gaps in the global sharing of knowledge. I want to determine what support governments require to sustain the involvement of private actors in private sponsorship, how Canada has approached this and what knowledge can Canada therefore share with other countries? Most significantly perhaps, what can Canada learn today from the refugee resettlement experiences of the U.K. and Germany's iterations of PSR?

Although there is substantial literature on the PSR model's effects and history in Canada, the academic literature on how this model is applied outside of the country is somewhat limited. The Global Refugee Sponsorship Initiative (GRSI), an initiative created in partnership with Immigration, Refugees and Citizenship Canada (IRCC), the United Nations High Commission for Refugees (UNHCR), the Open Society Foundations, the Radcliffe Foundation and the University of Ottawa, to promote global private sponsorship of refugees activities was launched in December of 2016. GRSI held a three day conference in Ottawa and hosted delegates from Argentina, Australia, Brazil, Chile, Germany, New Zealand and the U.K. All had come to learn about how the PSR model works in Canada and how it could be exported and adapted in different countries (Shane, 2017). In July 2017, GRSI's website of resources for communities 
interested in resettling refugees through private sponsorship went live online. The scholarly and media analysis of comparative PSR policies is currently an emerging field of study due to the recent nature of the model being implemented in different countries, and thus the global sharing of knowledge is also fledgling. My analysis of Canada exporting the private sponsorship model, a model which policy makers around the world are hoping to utilize and learn from, will add to the literature on comparative refugee resettlement policies between Canada and other nations.

\section{Scope}

The scope of my research includes communities taking part in private sponsorship in Canada, the U.K. and Germany. The research will not address countries in the global south that are interested in implementing a private sponsorship model for refugee resettlement. The GRSI has a monthly newsletter that updates its audience on how different communities are using its resources, including those in the global south. In the future, further studies could examine the emerging role of PSR in Argentina, Brazil and Chile. Qualitative human interviews were not conducted with sponsors or sponsored refugees in Canada, the U.K. or Germany. This is due to the limited time frame of the project as incorporating these perspectives requires more attention and additional skill sets. However, I envision that including these voices would be extremely beneficial for future research on this topic.

The U.K. was chosen as a site of study in part because of the availability of English language sources about its community sponsorship model. Ireland, Australia and New Zealand are also English-speaking countries that are developing PSR models (GRSI, 2016). However, the U. K.'s community sponsorship program has developed extensively since its inception in 2015, with over 200 refugees, 140 community groups, and 300 local authorities involved in community 
sponsorship (Citizens UK, 2019, Government of the U.K., 2019). Other countries that are hoping to implement community sponsorship initiatives may also look to the U.K. as a case study in how to introduce and implement private sponsorship.

Germany was chosen as a secondary case study because of its leadership regarding Syrian refugee resettlement policy in Europe. Syrian refugees can enter Germany for two years on humanitarian grounds on renewable visas (ICMC, 2017). However, until the launch of NesT in May 2019, private sponsorship of refugees was restricted to people sponsoring their own family members (ICMC, 2017). Germany's current primary stage of its PSR model provides an interesting parallel and analysis to the U.K. and Canadian models.

The research for this paper was conducted in Osnabrück, Germany in the summer of 2019, having successfully secured funding with the Mitacs Globalink Research Award to complete this project. I participated in an exchange partnership between the Immigration and Settlement Studies (ISS) program at Ryerson University in Toronto and the Institute for Migration and Intercultural Studies (IMIS) and Master of Arts in International Migration and Intercultural Relations (IMIB) in Osnabrück, Germany. During my time in Osnabrück, I was able to attend a number of classes provided by the IMIB Masters programs and access syllabi with peer reviewed academic articles in English on the German migration scheme.

\section{Methodology}

The research methodology for this paper takes the form of an integrated literature review. This can be a useful strategy to employ when comparing different models of PSR for several reasons. Firstly, it is important to understand the conversations around private sponsorship, to identify and integrate new scholarships, and generate innovative understandings (Ravitch \& 
Riggan, 2012; Torraco, 2005). Integrated literature reviews also provide methods to protect validity and trustworthiness at each step of the study (Russell, 2005) such as being as explicit and transparent as possible. All of the documents used for this research are publicly available. Researchers interested in replicating my study may use the same guiding theoretical frameworks and methods to get consistent results. The study also serves in part for the fulfilment of my Master of Arts degree at a Canadian university, and as such is peer reviewed by fellow academics.

The main literature for this paper was gathered through an analysis of English language books and peer-reviewed academic articles. Secondary data was gathered from grey literature like government websites and documents from IRCC, the Government of the United Kingdom, and the European Union. Information was retrieved from using Google Scholar, Ryerson University Library \& Archives, and the Institute for Migration and Intercultural Studies Library at the University of Osnabrück. Key word searches used terms including 'private refugee sponsorship', 'refugee resettlement', 'refugee policy', 'refugee sponsors' in combination with 'neoliberalism', 'social democracy', 'localism' and 'immigration' in Canada, the United Kingdom and Germany.

Comparative research in migration studies occurs more often in Europe due to the proximity of the countries to one another (Bloemraad, 2013). Recent immigration and comparative studies between Canada, Germany and other European countries have typically focused on labour migration policies (Finotelli \& Kolb, 2017), knowledge sharing of restrictionist asylum policies (Soennecken, 2015) and membership politics, multiculturalism and citizenship (Triadafilopoulos, 2012). However, this paper extends this comparative analysis framework to private refugee sponsorship methods centered on the idea that: "you cannot know 
what is unique, or common, about a particular case unless you have a comparative point of reference" (Bloemraad, 2013, 42).

To complement the main integrative and comparative literature review, the research also consists of a brief qualitative document content analysis of the written publications and reports, videos, fact sheets, guidebooks, news media and additional promotional materials from two electronically accessible web portals about the PSR model. The web portals are the Global Sponsorship of Refugees Initiative and the Government of the United Kingdom's materials on the Community Sponsorship of Refugees program. The sample for my document content analysis consists of three guides, seven videos, and one leaflet from the government of the United Kingdom, and the GRSI's guidebook (which includes planning tools based on Canada's model), three videos, twenty newsletters, five press releases and four fact sheets. My study does not use or harm human subjects or create damaging opinions about refugees themselves. As it is a literature review, there are no ethical concerns regarding in person interviews.

In addition, I analyzed a selection of online and print media news articles about PSR in Canada and the U.K. from news media such as the Canadian Broadcasting Corporation (CBC), The Globe and Mail, The New York Times, The Guardian as well as articles from local news outlets in the U.K. Evaluating the content produced about private sponsorship from these sources works to highlight how the model is being promoted to its relation about how it is operating in practice. Using these sources in a brief qualitative document content analysis in conversation with peer-reviewed academic literature integrated into theories of neoliberalism, social democracy and localism illustrates current developments in how countries and communities are adapting to private sponsorship, given its status as a relatively new concept and policy in Europe. Document content analysis is helpful in gaining insight on privately sponsoring refugees in the 
U.K. because in comparison to Canada, there is a limited amount of academic literature written on this topic. The document analysis occurs alongside the literature review in Chapters 4-6 and in greater detail in Chapter 7.

\section{Data Collection}

Using grounded theory, I examined the literature and the sources used for the content analysis with my guiding research questions: how is PSR being adapted in different geopolitical contexts and how is the model and the refugees themselves being represented? O'Leary's (2014) steps of planning a process for document analysis was an invaluable tool for this paper. One of the steps is to acknowledge bias. As previously mentioned, I am biased towards these sources because they are available in English. For data collection tools I used keyword searches throughout the documents, for words such as 'success', 'hope', 'fear', 'community strength' 'benefit', 'family' and 'refugee' and recorded my notes in an organized Microsoft Word document. I also analyzed for latent content in my sources for themes such as 'government support', 'global responsibility' and 'images of refugees'. These themes helped to inform my argument that PSR is a viable option that should be encouraged in the U.K. and Germany. This is provided that the number of refugees admitted through PSR should not surpass numbers of refugees admitted through government sponsorship. Effective oversight and evaluation should be administered by governments and NGOs towards groups and communities involved in private sponsorship, and that diverse images and perspectives of refugees themselves be used in the promotional material created by governments and NGOs about private sponsorship. I organized ideas and concepts that clustered together to generate themes that emerged from the collection 
process (Bowen, 2009). In interpreting my data, I referred back to my theoretical foundations of neoliberalism, social democracy and localism to connect the materials to these themes.

Cost-effectiveness and the availability of sources are the strengths of my research being a standalone integrated literature review and a limited qualitative document content analysis. As those outside of academia are able to access my dataset, my audience is able to view and interrogate these sources as well. Analyzing these documents can help track changes and developments in the PSR method. The shortcomings of doing a document content analysis of sources that are created by government agencies is the potential for a lack of voice and representation of privately sponsored refugees who have had negative experiences with the model. This is also a form of biased selectivity (Bowen, 2009). Getting access to interview privately sponsored refugees as well as sponsors in the U.K and Germany, however, would have been very difficult given the time sensitivity of the project.

\section{Researcher Self Disclosure}

I acknowledge that the paper's paradigm is shaped by its intended audience in addition to my wish to contribute to the existing literature on PSR models. Students and scholars interested in issues of immigration and settlement in Canada, the U.K., and Germany, policy makers and civil servants at IRCC and other governments and communities around the world invested in developing PSR models are the intended audience of this research.

I want to be critical but not so that it defeats the quest for practical knowledge (Kvale, 1995). The literature draws attention and concern to the marginalization of refugees and sponsors who argue that the Canadian government heavily relies and may even take advantage of sponsors (Lenard, 2016; Ritchie, 2018; Labman, 2016). I do not intend to ignore or dismiss the arguments 
and claims advanced by their research and critical perspectives, indeed their work is part of the literature review that is informing my knowledge about the program in Canada.

I understand the importance and need for participatory research about private sponsorship which deliberately includes the perspectives of refugees themselves. They should be part of the planning and knowledge creation process of refugee resettlement policy because it impacts their lives and the lives of other refugees (Simich, 2003). While I agree that a participatory paradigm would be beneficial in informing the knowledge about the successes or challenges of private sponsorship, I am cautious of my own limitations and experience as a researcher and know ethical considerations must be met when consulting this vulnerable population. Block et al. (2013) states that researching young people with refugee backgrounds requires acute awareness of power imbalances, negotiating informed consent and ensuring that interactions are not merely tokenistic. As such, I acknowledge that not doing qualitative interviews with refugees who have been privately sponsored is a limitation in my research. However, to engage with this important viewpoint I draw from the existing literature which includes qualitative interviews with refugees. Their perspectives and experiences with private sponsorship by religious, academic, business, and community groups enlightens my own research. In his research on privately sponsored Syrian refugees in Alberta, Agrawal (2018) found that they face similar resettlement challenges, such as learning English and gaining employment, as much as government assisted refugees and blended visa office referred refugees do (BVOR). Comparing the experiences of organizations and sponsors is also important (Lamphier, 2003). Contrasting refugee experience with the community success outcomes that are promoted in the private sponsorship materials used for my content analysis adds nuance and depth to this paper's goal in determining practical concerns for refugee resettlement. 
My interest in pursuing this topic came from a short one to one meeting with The Honourable Ahmed Hussen, Minister of Immigration, Refugees and Citizenship Canada (IRCC) at Ryerson University on December 14th, 2018. The Minister was giving a speech and hosting a question and answer period about the Global Compact for Safe, Orderly and Regular Migration (GCM) which he signed a few days prior at the United Nations Intergovernmental Conference in Morocco (IOM, 2019). The Ryerson Leadership Lab was hosting the event and I was asked to give the closing remarks. He heard that my research interests were in comparative immigration policies and that I would be in Germany at the University of Osnabrück for the summer of 2019. The Minister said that Canada was working with Germany to help advise them on how to implement a PSR model, and thus my intrigue in this topic stemmed from this piece of information. Although I may have become aware of this topic in the course of my studies, it is without a doubt that this meeting influenced my decision to pursue research of this phenomenon. 


\section{CHAPTER 4}

\section{Years in the Making: Canada's Private Sponsorship of Refugees Program}

\section{History of the Private Sponsorship of Refugees Program}

Before the 1976 Immigration Act, Canada operated on a somewhat of an ad-hoc refugee intake policy that saw civil society groups assisting with bringing refugees into the country after the First and Second World Wars (Hyndman et al., 2017). In the post war years, Canada signed the United Nations 1951 Refugee Convention and in 1956 welcomed asylum seekers from Hungary fleeing the Cold War communist regime (Kelley \& Trebilcock, 2010). This was one of Canada's largest refugee resettlement programs. 37,000 Hungarian refugees were resettled during a twelve-month period between 1956-1957 (Adelman, 1982). The resettlement was a concentrated and organized response to aid in the humanitarian effort towards this global crisis. However, rather than setting a precedent for refugee policy, the move was considered more of a one off for Canada (Troper, 2003). Hungarians had arrived in Canada prior to 1956 but in much smaller numbers. The refugees who came as a result of the uprising in Hungary were part of a "4th Wave" Hungarian movement to Canada, many of whom made their home in Toronto (Keyserlingk, 1993). In 1961, the Canadian census found that Toronto's Hungarian population had increased by $109 \%$ as a result of refugee resettlement (Dreisziger et al., 1982).

In 1976, a new provision in the Immigration Act allowed for Canadian citizens and civil society groups to sponsor refugees from abroad. Sponsors were responsible for providing financial and social support for twelve months. The model was slow to gain traction. Yet in 1979, citizens and communities heavily utilized the new provisions to respond to the Indochinese refugee crisis as a result of the conflict in South East Asia (Csillag, 2017). Under the leadership 
of key individuals such as Howard Adelman and Ron Atkey, the Minister of Immigration at the time, "Operation Lifeline" was created as a resource network for passionate grassroots organizers who mobilized to support the resettlement process. The Conservative government of the day even added an additionality component to the private sponsorship program. For every government assisted refugee, the government matched with a privately sponsored refugee (Casasola, 2016).

The additionality component remains key to the PSR model, in Canada PSR was never meant to surpass the number of government assisted refugees, only to add to the existing quotas and numbers. This is something that other countries who wish to adopt PSR must also keep in mind to maintain the integrity of the model. The reasoning for this is so that PSR can operate as a complementary program to existing government resettlement efforts but not completely replace them. During the Sino-Vietnamese refugee crisis, the two programs worked in unison to prove to be a successful endeavor. Community support was high with Atkey commenting decades later that "it became very fashionable to sponsor a family" (Csillag, 2017). In 1986, Canada was awarded the Neman medal for its collective response to this global need (Labman, 2016). The Vietnamese Federation of Canada states that Atkey's humanitarian actions and leadership in the resettlement effort remain unparalleled (Csillag, 2017).

Private sponsorship continued into the 1980's with a large influx of Polish refugees who were part of the East European Self-Exiled Designated Class and sponsored by Polish Canadian groups. However, the Indochinese case would remain the largest resettlement effort in recent memory until 1999 when 5,000 refugees from Kosovo were resettled through private sponsorship (Casasola, 2016). Lam et al.’s (2014) study on privately sponsored Kosovar refugees found that although this group continued to seek assistance from their sponsors after the one year 
term, their independence increased and relationships became more "socially-based than assistance-oriented with corresponding reduced level of frequency of contacts" (4). Indeed, this parallels the changing and evolving relationship between privately sponsored Vietnamese refugees and their sponsors, the former identifying that their benefactors provided generous support which highlights how, "the type of sponsorship greatly determined the level and source of social support received by the refugees" (Ha \& Tyyskä, 41, 2019).

In 2014, a year before any large scale resettlement policy for Syrian refugees was put into motion by the Canadian government, the Toronto Star ran an article questioning if Canada could do the same for Syrian refugees as it did for the 'boat people' (Godspeed, 2014). The term 'boat people' has been used to describe the tens of thousands of people fleeing out of Vietnam on rickety ships in dangerous seas into neighbouring countries during the war. 35 years after "Operation Lifeline", leaders like Ron Atkey and Naomi Alboim- the federal coordinator for the Indochinese movement in Ontario, wanted to share how the lessons learned from this Canadian success story could be applied to the Syrian refugee crisis. They believed that Canada was not doing enough and needed to play a more active role in the resettlement process like it had done in the past, such as increasing the numbers of admitted Syrian refugees (Godspeed, 2014; Csillag, 2017; Alboim, 2016).

Looking at the experiences of Vietnamese and Syrian refugees is an important and useful comparison. Although Vietnamese and Syrians do not share a common language, history, or culture, what they do have in common is their relationship to refugeeness in Canada. It is important to qualify this refugee label because language, class, gender, age, ability and many more things all work to create an individual's identity and being a refugee or a former refugee is one part of a person's complex life story. It is necessary to ensure that people are not identified 
with monolithic markers that run the risk of fetishizing their traditions and cultures (Bannerji, 2000). However, the reason for comparing the Vietnamese and Syrian refugees is not only because of the connections activists and policy have drawn between the two but by the parallels of their unique life experiences.

In 2015 when the Trudeau government committed to increasing the number of Syrian refugees from 10,000 to 25,000, across Canada, many Vietnamese Canadians came together to raise funds to privately sponsor Syrian refugees (Caulderwood, 2015). In Toronto, the program "Vietnamese for Lifeline Syria" was launched, modelled after "Operation Lifeline" from the 1979 resettlement effort (Caulderwood, 2015). Members of the Vietnamese community involved in private sponsorship showed compassion towards the needs of Syrian refugees because they empathized with and understood the realities and difficulties of the refugee experience. Tom Tang, a former Vietnamese refugee believes that his community has been able to contribute to Canada because of the private sponsorship resettlement opportunity extended to them when they were refugees, and that the Syrians should have the same chance. He is quoted as saying, "We were in the Syrians' shoes back then and I think because the Vietnamese community has moreor-less been a successful integration that we need to come forward to show Canadians, our country, that taking in refugees is a good thing - we became tax paying citizens, we give back to the country" (Caulderwood, 2015).

Indeed, the release of the photo of Alan Kurdi's lifeless body on a Turkish beach marked a significant shift in framing the conversation about Canada's involvement in the resettlement process of Syrian refugees (Ramos, 2016). The option to privately sponsor gained increased traction amongst the Canadian public, and refugee issues became a focal point in the 2015 federal election (Alboim, 2016). Prior to the release of the Kurdi photo, in 2014, issues in Syria 
were generally framed in terms of war and conflict rather than Canada's need to become involved on a humanitarian level (Wallace, 2018). Information from the Conservative government regarding the refugee resettlement process was often limited as well as confusing (Alboim, 2016). However, the perception of sponsoring Syrian refugees continued to shift once the 2015 group arrived in Canada. In a content analysis of Canadian media coverage of the Syrian refugee crisis, over an eight-month period there were 17 news videos which depicted Syrian refugees as 'security concerns', and young Syrian men in particular were characterized as potential terrorists. The high profile refugee resettlement and willingness to privately sponsor Syrians is also occurring at a time of a global heightening in anti-Muslim sentiment. It is interesting to compare the historical and political significance of this with the acceptance and eagerness to help Hungarian and Indochinese refugees who were fleeing communist rule during the Cold War period, a factor that may have played a role in Canada's acceptance of willingness to support those escaping from these places.

Nevertheless, Canada's private sponsorship model has been touted as a success by Canadian news media and praised for its readiness for export to different countries looking to focus their efforts in alleviating the global refugee crisis (Shane, 2017; Harris, 2016). In February 2019 at an event in Windsor, Ontario that honoured 40 years of the PSR model, the Minister of Immigration, Citizenship, and Refugees Canada praised how along with government sponsorship, private sponsorship has brought in over 327,000 refugees to Canada (Thompson, 2019). The PSR model was unique to Canada and many Canadians hold a sense of pride of the model's history and how it is still being utilized today to respond to refugee crises. 


\section{Government Assisted Refugees}

Government Assisted Refugees (GAR) are refugees referred to the Government of Canada by the United Nations High Commissioner for Refugees (UNHCR) and receive support from the non-governmental settlement sector funded by IRCC for up to one year in areas such as accommodation, food, clothing, and orientation to Canadian society (IRCC, 2016). After cases are approved, refugees are subject to a medical exam, security screening and their biometric information is collected. Once they arrive in Canada they receive Permanent Residence status based on a well-founded fear of persecution for returning to their country of origin (Statistics Canada, 2019). Compared to PSRs, GARs also tend to have additional needs, as seen in the "Syrian refugees who resettled in Canada in 2015 and 2016" study by Statistics Canada. Young families with children, and those who were less likely to speak one official language made up the core demographics of Syrian GARs during this time. The government highlights how GARs may have greater labour market integration challenges than their Syrian PSR counterparts who tended to be older with knowledge of one of the official languages (Statistics Canada, 2019).

However, federal data about other groups of GARs and PSRs state that despite PSRs generally having more education and official language ability, there are no major differences in income earnings between the two (Hyndman et al., 2017). This data contradicts some of the positive literature on PSR that praises the model for generating better settlement outcomes like finding jobs and building social capital than GARs (El Chidiac, 2018; GRSI, 2016; Alfred, 2018; D’Addario et al., 2007). Past studies and data on this population have also argued that the experience of PSRs has been mixed (Carter, 2009; as cited in Silvius, 2016). 


\section{Development of the PSR Program}

Since its launch in 1979, the PSR program has evolved and been modified. Like with GARs, PSRs are supported by their sponsors who are responsible for securing accommodation, helping with labour market integration and life's daily necessities (IRCC, 2016; GRSI Guidebook, 2017, Refugee Sponsorship Training Program, 2019). Currently the ways to be privately sponsored are through being 'Sponsor-Referred' and 'Visa Office Referred'. The former allows sponsor groups to request the name of the refugee and the refugee family they would like to sponsor. This is a popular route that sponsors take to help their sponsored refugees reunite with their extended family members (Hyndman et al., 2017). The "Visa Office Referred" category matches sponsors with refugee cases already selected by IRCC but in need of a private sponsor (Silvius, 2016; GRSI, 2016). The PSR program is broken down further with different categories of sponsors. These are: Sponsorship Agreement Holders (SAH), community sponsors (also known as Constituent Groups), and Groups of Five. SAH's have special agreements with the government of Canada, they have the authority to recruit, screen and supervise sponsors. Community sponsorship groups are under the authority of SAHs but provide direct settlement support to refugees. Groups of Five are made up of a minimum of five Canadian citizens or permanent residents and are screened by IRCC (GRSI, 2017).

In 2013, another category in the PSR model was added, Blended Visa-Office Referred (BVOR) to help the government during periods of global instability and high refugee influxes as was the case with Indochina and Syria (Labman \& Pearlman, 2018). Government and private sponsors share costs and responsibilities through resettlement of refugees under this category, some of whom may have higher needs (Guidebook, GRSI, 2017; IRCC, 2018). 
However, amidst these developments and changes, one of PSR's lasting elements is its relationship with faith-based groups. Faith-based groups have been steady supporters and active participants in privately sponsoring refugees in the forty years that the program has been in place. The Canadian Christian Church has had a major role in influencing the PSR program, in fact, 75\% of private sponsors are supported by faith-based Sponsorship Agreement Holders, and the other 25\% are 'groups of five' (McKinlay, 2006). Faith based involvement extends into the mandatory training component for sponsors too. Catholic Cross-cultural Services (CCS) has had the contract for The Refugee Sponsorship Training Program (hereafter RTSP) since 2008 (GRSI, 2017). RTSP has existed since 1998 and provides in person and teleconference support regarding pre-arrival and post arrival issues for sponsors:

[RTSP] works with sponsors to ensure they have the knowledge and resources needed to successfully settle their sponsored refugees. The training topics include managing expectations, the ethical considerations in sponsorship, conflict resolution, understanding sponsorship disputes and breakdowns, handling secondary migration, planning for the end of sponsorship, and other important post-arrival matters such as mental health and domestic violence issues (Guidebook, Global Refugee Sponsorship Initiative, 2017).

Although the PSR program has developed with adjustments identified by government, private sponsors and sponsored refugees to better the experiences of those involved, the program has still been subject to critique by academics and advocates in the refugee resettlement sector. Primarily this has focused on the government's perceived actions of relying heavily on this model rather than using it as a supplement and complement to existing government assisted sponsorship. Because PSR has existed in Canada for over 40 years, Canada provides ample case studies that other countries can look at to see how they may address similar issues that arise for them. However, I am skeptical that this made in Canada program should be promoted as an effective, positive and cost-saving measures for other countries and governments without careful 
consideration of some of the program's major critiques in the Canadian context. Again, it is important to stress that the additionality principle, that works to ensure that private sponsorship is a complementing refugee resettlement program to existing government led ones, is a key component to a successful PSR model.

\section{Critiques of the Canadian PSR Program}

Critiques and comments regarding the PSR program began to emerge after the initial wave of resettled Indochinese refugees in the 1980's. Woon (1987, as cited in Ha \& Tyyskä, 2019) highlighted how privately sponsored Vietnamese refugees felt that ambiguity and confusion plagued the program. Even after arriving in Canada, the rules and the policy were never made clear to them. They were unaware of the financial requirements and length of time that their sponsors were committed to them which resulted in anxiety over the terms of contract for sponsorship. Ha and Tyyskä (2019) also note how; "there is no actual parallel in Vietnamese culture that explains the idea of private sponsorship. This type of charitable act where one would help a complete stranger was unheard of, as the norm in Vietnam was to only receive the help of family or close community members" (p.37). Private sponsorship has been praised for its ability to foster two way integration (Alboim, 2016; Alfred, 2018; UNHCR, 2016). However in the early years of the program given the expedited resettlement process and sense of urgency for refugees to be resettled, key communication and cultural awareness preparedness was missed in preparing the sponsors and refugees for their arrival.

This was an early indicator that governments and NGOs should administer effective oversight, evaluation and monitoring over sponsor groups. For the U.K., Germany and other countries interested in developing their own PSR model, this is something important to keep in 
mind when selecting refugee families for this stream. Not just sponsors, but sponsored refugees should be as prepared as they possibly can be. They should have all of the information necessary to ensure that their initial settlement is not one of confusion or ambiguity regarding expectations towards their hosts. The goal is to encourage more nations to adopt this model, and if this is the case then a greater number of refugees around the world awaiting third country refugee settlement need to receive the relevant information and become more aware of the nuances surrounding private sponsorship. The opportunity to resettle in the developed north is still not an opportunity for many people (Easton-Calabria \& Omata, 2018).

A potential risk of this model is that privately sponsored refugees may find themselves in precarious circumstances with their sponsors who may not have adequate cultural competency to respond to their sponsored group's needs (Lenard, 2016). I understand cultural competency as the ability and willingness for sponsors to respect, understand and accommodate the religious, dietary, cultural, familial and specific and unique needs of those they are sponsoring. Cultural competency is also contingent on relationship building where the principles of trust, equitability and fairness are foundational in understanding the expectations and attitudes of others (Refugee Assistance Program Workers, n.d).

Cultural incompetency occurs when sponsors disregard these needs and instead try to assert their own beliefs or methods of doing things which they value more and above the beliefs and methods of those they are sponsoring. Pre-existing opinions about refugees or different cultures may be hard to overcome for people acting in a volunteer capacity (Erikson, 2012) and increasingly neoliberal policies are relying on volunteers to fill the gaps and needs that should be administered by state service providers. For example, in the U.S. governments regard that private volunteer agencies offer a more responsive and humanitarian approach to refugee resettlement 
(Gonzalez, 2016). This has the potential to make the refugees feel uncomfortable, disrespected or powerless against their sponsors who may not be able to strike a balance between being helpful and being intrusive. Past studies have "found cases of excessive intrusiveness of sponsorship groups in the lives of refugees" (Hyndman et al., 58, 2017). Resentment and the pressure to feel grateful can brew between those sponsoring and those being sponsored, and it highlights how this system relies on the establishment and existence of trust. Indeed, there is a high element of dependency that the refugees have towards their sponsors; "to make decisions and to take action to address challenges" (Easton-Calabria \& Omata, 2018, 1463). Better oversight is needed from the government to ensure that sponsored groups are not completely vulnerable and dependent on the people who are sponsoring them (Lenard, 2016). Under private sponsorship, a fine balance needs to be struck so that privately sponsored refugees develop not only resiliency and independence from their sponsors, but also feel respected and that they can turn to them for help.

Although there is real potential for sponsored refugees to be subject to this, better and increased support networks for sponsors themselves may help mitigate and minimize this risk. Comprehensive and detailed background information about the specific cultures and experiences of the refugee groups they will be engaging with would benefit the settlement experience for both parties (Ha \& Tyyska, 2019). El Chiadiac's (2018) call to action in support of private sponsorship is for organizations like think tanks, as well as academics to increase their research in this model and share their findings. This work will help answer questions about how to give communities greater support and involvement with private sponsorship, rather than trying to see how governments can do more.

It is tempting to believe that private sponsorship can be an effective and positive response to addressing the lack of resettlement options for many people around the world. However, PSR 
should exist in unison and as a complement to existing government resettlement programs, it should not be a standalone or considered the ideal model of resettlement over government assisted refugees, despite praise and personal anecdotes that the program is superior in quality to other existing refugee resettlement avenues. Although the type of research that El Chiadiac is calling for would indeed be beneficial, and I hope that this paper is part of that call to action, it should not be utilized to encourage less government intervention or as evidence to withdraw funding from the GAR or BVOR programs just because PSR is thought to be a more viable option for success and integration. The implementation of BVOR has also been met with concern, Sivius (2016) argues that;

... while (BVOR) may be deemed attractive to sponsors who are simply looking for 'any refugee' to sponsor because of supposed faster visa processing, there is a legitimate fear that it does not fully respect the additionality principle, insofar as government retains the power to influence which refugee is eligible for selection (36).

Before BVOR was implemented in 2012 the Conservative government's decision for global caps on private sponsorship applications gave them the power to prioritize certain refugee populations over others (Silvius, 2016). This is similar to the prioritizing of Indochinese refugees during the late 1970s (Casasola, 2016). The caps have been critiqued for jeopardizing the additionality principle which in the past has allowed sponsor groups to name refugees from certain groups or countries that they wish to sponsor.

With this in mind, Canadians have still been keen to aid in the refugee crisis and private sponsorship has often emerged as a popular humanitarian response and solution in the public consciousness during times of crisis (Ritchie, 2018). In 2018, IRCC committed to admitting 18,000 privately sponsored refugees, acknowledging that as compared to previous years the larger number speaks to the interest and success of the private sponsorship program (IRCC, 
2018). In 2019, the numbers increased further with 19,000 Syrian refugees arriving through the PSR stream and 10,500 arriving through other refugee resettlement programs (IRCC, 2019). In an effort to try and clear its backlog, the Government of Canada has implemented a multi-year levels plan to better adhere to the twelve month processing timeline, settle more refugees over a three year period and limit the number of new applications they will be accepting (IRCC, 2018). The amount of time it takes to process private refugee sponsorship applications has been criticized by faith-based groups, settlement agencies, politicians and individual private sponsors (Canadian Unitarian Council, 2019; Ireland, 2016; Hyndman et al., 2017; Alboim, 2016). In 2015-2016, during the height of the Syrian and Iraqi conflicts and these group's refugee resettlement period in Canada, IRCC allowed sponsorship groups to sponsor refugees who had not received official UNHCR designated refugee status, this exception has since been terminated (El Chidiac, 2016).

It is important to question who is being left out of and who does not benefit from a PSR model. As Chapter 7 highlights, the focus on images of families with young children as beneficiaries of the PSR model can work to exclude those who do not match this image such as single men or elderly individuals. In Canada, those who are selected for PSR generally also have higher education levels and less medical needs than those who are brought in through the government assisted stream. Canada's relatively isolated geography means that it does not face the same surge of population movement that European countries do. This coupled with private sponsorship allows Canada to be even more selective in their admittance of refugees than its European counterparts. At GRSI's launch in December 2016, John McCallum, the former IRCC Minister made it clear that privately sponsored refugees would in no way be treated 'better' than 
Canadian born citizens in terms of access to social services and would never be at the 'front of the line' before Canadians who were in need of these same services (Harris, 2016).

\section{CHAPTER 5}

\section{Community Sponsorship in the United Kingdom}

\section{Forming Community Sponsorship Policy}

Compared to Canada's decades long history with the PSR program, the U. K.'s Community Sponsorship program did not exist until 2014. The images and events from the conflict in Syria served as a catalyst to propel citizens from many communities to act. In interviews with various news media outlets, community sponsorship groups in the U.K. cite this time period as one when serious considerations for private sponsorship of Syrian refugee families began (Fenton, 2017; Cheslow, 2018; Salvation Army, 2019, For Refugees, 2019, Phillimore \& Reyes, 2019). In 2014, the government announced two initiatives to respond to the Syrian refugee crisis, the Vulnerable Persons Resettlement Scheme for Syrian nationals and the Vulnerable Children's Resettlement Scheme. Both of these programs broadened to include refugees from the Middle East and North Africa, but civil society still continued to push for the inclusion of a private sponsorship model similar to Canada's. Communities in Wales and England began working with the Home Office, their Local Authorities, and with each other to develop strategic community sponsorship plans outlining how they would support a refugee family in their community. The U.K. began to welcome their first refugee families in October of 2015 and in June 2019 announced that the number of refugees admitted through community sponsorship would expand in 2020 (Sponsor Refugees, 2019; Government U.K., 2019). 
It is important to note that prior to this announcement the U. K.'s community sponsorship program only focused on sponsorship of refugees from Syria. Through private sponsorship, the identity of refugeeness is questioned and interrogated, as well as notions about who is considered a refugee or who is deserving or undeserving of community sponsorship. The existing promotional material tends to showcase families consisting of a mother and a father with young children and/or babies, even though these are not the only types of families that are sponsored. Having a diverse range of representation of privately sponsored refugees would showcase the variety of family structures and people involved in private sponsorship. Although images of families with young children are palatable to audiences and potential sponsors who may want to help such a group, authentically representing the PSR program and its people is crucial so that those who fall outside of this nuclear family structure are also seen and helped.

In a recent qualitative study of initial community sponsorship groups and sponsors in the U.K., refugees who did not have young children enrolled in primary or secondary schools were reported as having lower English language acquisition because of a lack of informal opportunities, such as speaking to other parents to practice the language (Phillimore \& Reyes, 2019). The authors also found challenges with the mismatching of rural and urban placements. some refugee families struggled to adapt to their new surroundings. Families who had lived in urban centres in Syria were placed in small towns and villages, and those who came from smaller places in Syria were placed in larger municipalities in the U.K. High social isolation rates were also reported among women who acutely felt the lack of an Arabic speaking community around them (Phillimore \& Reyes, 2019)

Phillimore \& Reyes's (2019) study is one of the first publications on community sponsorship in the U.K. that highlights challenges that both refugee families and sponsors face. 
This reality has not necessarily been highlighted in the promotional materials on private sponsorship from the U.K. government, in local news media reports on communities welcoming families, or promotional materials from NGOs that have partnered with the Home Office to support communities looking to engage in community sponsorship. However, Phillimore \& Reyes (2019) found that these initial problems should not discourage community sponsorship from growing in the U.K. The establishment of Reset, a body similar to its Canadian counterpart, the Catholic Crosscultural Services of Canada, which provides streamlined training for community sponsorship groups, has already mitigated some of the issues that have arisen. These include sharing knowledge regarding the application process, integration and employment barriers for refugees, and managing cultural differences.

\section{Localism and Community Sponsorship}

The way the U.K. has adapted their version of the PSR model could be a response to the influence localism has had in the country. The language on 'community' sponsorship rather than 'private' sponsorship, focuses on the community as a whole to provide support, rather than individual actors or single faith-based groups. Like in Canada, in the U.K. faith-based groups are heavily involved in sponsorship initiatives. Indeed, 'community' sponsorship tends to evoke images and sentiments of collective effort, community strength and growth, as well as humanitarian responsibility. Videos created by the GRSI, Citizens U.K. and the Salvation Army showcase members of various sponsorship groups speaking about their role in the process. They highlight each individual's contribution to the collective effort while still packaging the experience of private sponsorship as primarily a community initiative and undertaking. 
Before community sponsorship groups can be approved by the Home Office to be eligible to participate in the scheme, they need to gain approval from their Local Authority. This stipulation has caused some friction between Local Authorities and the citizens who have come together with a sponsorship plan. The Tottenham Refugee Alliance halted their plans in submitting a proposal to their Local Authority citing a bad relationship with the administration (Allin, 2018). Local Authorities have the power to reject admittance of refugees on a number of grounds including pre-existing medical conditions and a lack of available schools in the area (Phillimore \& Reyes, 2019). This echoes Mills's (2012) beliefs that refugees with special and particular needs are more affected by local agendas that do not support their inclusion into the community. Combined with the fact that the U.K. does not have a national framework regarding integration, community sponsorship groups and local authorities hold an incredible amount of responsibility over the families they sponsor.

Community sponsorship has now existed in the U.K. for the past four years and has gained increased visibility and traction with Members of Parliament such as Helen Hayes (Feldman, 2019) and Caroline Nokes, the Minister of State for Immigration until July 2019. The two publicly support community sponsorship in and outside of the House of Commons, more news coverage and promotional materials from organizations like Reset and other NGOs is being created, and over 300 community sponsorship groups exist in the U.K. today. With localism as a guiding principle of the U.K.'s policy, it is likely that community sponsorship will continue to exist, grow and expand. Its increasing popularity as a means for citizens to become directly involved in what may seem to be an insurmountable global issue fits well within the U.K.'s existing policies and ideologies that put emphasis on the power and strength of communities and local authorities with existing but marginal national oversight. Although the method is adapting 
to the needs and concerns identified in studies like Phillimore and Reyes's it is also imperative that because this is still a relatively new phenomenon and initiative in the U.K., that research, evaluation, monitoring and oversight be conducted with resettled refugee families as well as sponsors so that their experiences can be properly captured and improved upon. With the Home Office's recent announcement to expand the numbers of refugees admitted and increase the number of countries eligible to participate in the scheme, it is starting to more closely resemble the Canadian model, yet with stronger elements of localism than neoliberalism. Critics like Rolfe (2016) take issue with the U.K. government's reliance on localism, stating that in reality, the government's emphasis on power in the Local Authorities is in fact neoliberalism. However, in the context of community sponsorship and refugee resettlement policy, the U.K. has capitalized on a method of refugee resettlement that has won public and private support and this could lead to increased backing and opportunities for communities and sponsored refugee families. 


\section{CHAPTER 6}

\section{Emerging Private Sponsorship in Germany}

\section{5: First Responses}

As was the case in Canada and the U.K., the framing of the conflict and displacement of Syrians as a humanitarian crisis by state actors and news media in Germany propelled not only government, but also members of civil society into action. They perceived an urgency to become more involved with activities to support refugees such as financial donations and welcome receptions at train stations and airports (Hinger, 2016; Fleischmann \& Steinhilper, 2017). Germany has been a leader in Europe in accepting and responding proactively to refugee resettlement initiatives. German "Willkommenskultur, the new culture of welcome" (Hinger, 79, 2016) or Welcome Culture, has been promoted as an attitude for citizens to adopt and show towards newly arrived refugees in Germany.

There were a number of policies that lay the groundwork for Germany to seriously consider private sponsorship. Syrians can enter the country on humanitarian grounds and stay for two years on a renewable visa through its Regional Admission Programmes (ICMC, 2017). However, the Humanitarian Admission Programmes allows Syrians in Germany to privately sponsor their family members who became refugees as a result of the conflict and who are in need of international protection (Salono \& Savazi, 2019, European Commission, 2018). Restricting the ability to privately sponsor only family members has proved somewhat of a limitation. A few states in Germany started to allow community groups to work together with people sponsoring family members from Syria (European Commission, 2018). 


\section{Changes, Developments and Going Forward}

An expansion of this model called Flüchtlingspaten Syrien began to take shape that more closely mirrored community sponsorship. High earning Germans with no familial ties to refugees were allowed to act as "godparents" and offer support to assist with the heavy financial costs of privately sponsoring family members (ICMC, 2017; Bathkes, 2019). Those involved in Flüchtlingspaten Syrien, the Godfather/Godmother program, are responsible for committing to financial and social support for their sponsored refugees for up to five years. There are also options for people to donate money to the program on a monthly basis if they do not meet the high financial obligations required of sponsors (Flüchtlingspaten Syrien, 2019)

In 2016, Germany attended the conference and launch of the GRSI in Ottawa and since then the country has been interested in utilizing the available resources that are being offered from Canada to design their own robust and effective private sponsorship program. IRCC, the GRSI and NGOs such as the Inter-Cultural Association of Victoria have travelled to Germany and worked with German government officials and policy makers in the field of immigration to grow Germany’s private sponsorship program, the largest in Europe (GRSI, 2018; Lehr, 2018; European Commission, 2018). This cumulative effort has resulted in the creation of the new German refugee resettlement program, "Neustart im Team" (NesT). NesT was launched in May, 2019 and aims to settle 500 vulnerable refugees who will arrive to the country in the late summer of 2019. Community groups of a minimum of 5 people will provide financial and social support (GRSI, 2019; Bahke, 2019, BMI, 2019). Unlike the Humanitarian Assistance program, sponsors no longer need to have a family connection to the refugees they are sponsoring. This is a marker of the growing support for private sponsorship among civil society in Germany as it extends 
outside family members and high earning German citizens to 'ordinary people' becoming directly involved in the work.

\section{Social Democracy and Private Sponsorship in Germany}

The growth of the PSR model in Germany can be related to the evolving nature of social democracy in general. Berman (2014) argues that social democracy is now more concerned with building community and shared values over dismantling capitalism. Indeed, by facilitating private sponsorship and broadening its scope to allow more potential sponsors who are interested and willing to participate in the German scheme is a marker of how elements of social democracy are still relevant and important to Germany and in Europe in general. Like in the U.K. and Canada, communities and municipalities in Germany with a strong sense of shared values are increasingly becoming actively involved in immigrant integration initiatives. Schmidke (2014) argues that cities and regions in Germany are becoming key players in governance and policy with regards to refugee resettlement but critically notes that this is more of a "marketbased management approach" (93). To what extent does the lens of social democracy apply to how Germany has developed its PSR program when looking to Canada as its model? I believe that although the German program is in its early days, elements of social democracy still outweigh the neoliberal aspects or criticisms of private sponsorship. For example, justice, solidarity, co-operation and community development- key elements of social democracy, are achieved with how the PSR model will operate in Germany. Germany is also respecting the principle of additionality. As a pilot program NesT is starting with a few hundred refugees to add to its refugee admittance numbers. If the program is evaluated to be successful, the number of 
refugees admitted through NesT will grow while not replacing the number refugees enrolled in existing pathways.

\section{CHAPTER 7}

\section{Promotion and Reception of Private Sponsorship}

As discussed in Chapter 3's methodology section, I conducted a brief qualitative document analysis using a grounded theory approach. The sources used were promotional materials from the GRSI and the Community Sponsorship of Refugees program from the Government of the United Kingdom. A selection of online and printed media news articles regarding the promotion and reception of PSR in Canada and the U.K. were also used. The content analyzed is discussed in conversation with one another under the identified themes. Themes that arose from the analyzed content are: 'ordinary citizens becoming extraordinary', 'community strength', and 'families: first and foremost'. These themes work together to reinforce certain expectations, images, and beliefs about private sponsorship today. However, the audience for these promotional materials is not so much the refugees, but rather for potential sponsors. The focus here tends to fall upon depicting how community sponsorship can benefit communities, particularly in the U.K.

\section{Ordinary citizens becoming extraordinary}

This theme speaks to how any individual can become involved, take action, and contribute to achieving extraordinary outcomes for the collective group effort. In the GRSI video titled, "How communities sponsor refugees: Canada's program", the voice over states that, "anyone can be a sponsor, sponsors come from many different backgrounds and experiences, but 
they all offer the same thing money, time and expertise to newcomers as they settle into the community" (GRSI, 2017). This idea that anyone and everyone has the ability to become involved in community sponsorship runs throughout the personal anecdotes and testimony from sponsors in the Canadian and British promotional material.

In the GRSI titled video, "Community Sponsorship in the U.K.", community sponsorship members in the two communities of Fishguard, Wales and Manchester, England reiterate the theme that anyone can do the job of supporting a refugee family, perhaps in an effort to encourage people who had never thought about being involved in such an initiative to do so. Testimony such as, "anybody can prepare a home, anybody can take somebody to a GPs practice, anybody can show them the surrounding area", work to reinforce the belief that these mundane tasks that 'ordinary' people do can actually be truly appreciated and necessary in assisting newly arrived refugees. Anecdotes like this allow potential sponsors to feel that they become more caring and empathetic people for assisting with this cause. This sentiment is also echoed in the U.K. government's pamphlet titled “Community Sponsorship Scheme”, where a highlighted quote from a member of the Manchester St. Monica’s sponsorship group says, “any community group coming together can make it happen, it's just the power of the people". This type of language, although empowering and hopeful, could also benefit shifting to be more reflective about the resiliency and power of the sponsored refugees themselves.

In another video from GRSI titled, "Sponsorship experiences”, which profiled a private sponsorship group in Newfoundland, many of the interviewees spoke about how their ordinary actions resulted in extraordinary outcomes for the people that they sponsored. Speaking about one of the children part of the sponsored family, a member of the group said; "He might not have to hear another bomb again... and we've had something to do with that, that's amazing". Another 
member shares that, "It's great to see them grow up and know that I was a part of it". This is strong testimony to try and convince potential sponsors about the benefits of being involved in this scheme, yet not everyone can participate in private sponsorship in such an active way. In an effort to promote private sponsorship to more people and potential communities outside of ones that are faith based, rural, or already actively concerned about refugee issues, "Reset", the organization recently created and contracted by the Home Office to provide training and support to community sponsorship groups, has a framework and toolkit for volunteers interested in spreading the word about private sponsorship through various social media and communication channels (Reset, 2019). This will prove to be a very useful tool in the German and the U.K contexts as the PSR model is still a relatively new initiative that more citizens and residents can learn about. Compared to these two countries, PSR is relatively more well known in Canada due to its long history. However, this communication campaign could also be a useful strategy to employ to encourage support and conversation for refugees even after the official contract is completed.

To what extent does this theme of "ordinary citizens becoming extraordinary" work to sell the idea of private sponsorship in Canada, the U.K., and Germany? Moreover, is it really fair to believe and state that just about everyone can become a sponsor or be involved somehow? In the "Community Sponsorship in the U.K." video, one of the members interviewed jokes that their sponsored refugee family of five is dealing with a twenty-person team. Indeed, this is certainly beneficial to the community sponsorship group to prevent burnout and fatigue. However, this may be confusing if the team structure and roles are not articulated accurately to the sponsored family. In practice, the theme of 'ordinary citizens becoming extraordinary' is not being promoted to the refugee groups as a way of learning about the PSR model. Rather the 
theme works to encourage its primary audience, that is, community groups, local authorities, NGOs, to become involved and support refugees through PSR.

Promotional materials also assure that support will be available for sponsorship groups and provided by refugee resettlement professionals and experts. With the blurring of the lines and overlapping roles and responsibilities between refugee resettlement professionals and 'ordinary citizens', it is in the government's best interest to have this partnership and collaboration with the voluntary sector and with civil society groups. However, it is imperative that the state must not withdraw oversight and monitoring completely. They must try to do both, to empower local communities to feel prepared to privately resettle a refugee family, but also do their part in ensuring that no harm comes to these individuals and that the system is evaluated and monitored for quality assurance. The GRSI monthly newsletters contain a section which highlights how a particular community has been strengthened by private sponsorship. In the May 2019 newsletter, the Mennonite Central Committee (Canada) stated that members in sponsorship groups should have clearly defined roles, create plans, and adhere to a code of ethics. Following this, in the June 2019 newsletter, the profiled sponsorship group stated that anyone can be a sponsor, and things will simply fall into place. While it is true that ordinary people are certainly capable of doing extraordinary things, and that seemingly small actions can indeed have positive ripple effects, the focus on the community sponsorship group doing these tasks, overshadows the extraordinary actions and resiliency of the sponsored refugee groups themselves who are integrating into a new community. Promotional materials and reception efforts should also highlight these perspectives and experiences. 


\section{Community strength}

Building and strengthening communities, coming together and thriving, are all terms that are evoked when highlighting PSR's benefits in promotional materials from the U.K. and the GRSI. In the GRSI video, "How communities sponsor refugees: Canada's program”, the model is said to make, "communities more welcoming places, when communities open doors to newcomers, they open their hearts and minds". The effects that community sponsorship has had on group members is a popular topic when reporting on this model in the U.K. The articles sampled from local news media outlets discuss and explore how the sponsorship group came to be formed and how the process is going, with minimal interviews or testimony from sponsored refugees themselves. Again, community sponsorship has only existed for just a few years in the U.K. so the reflection that is required to shape the program moving forward is still in progress. Research such as Phillimore \& Reyes' (2019) recent study on community sponsorship in the U.K. will increasingly begin to qualify varied experiences with the model soon. However, in Canada, the news media analyzed shows more of a balance between sponsors and refugees who were or are being sponsored. Because of PSR's 40-year history in Canada, news media stories not only focus on how private sponsorship changes communities, but also the effects the model has had on formerly privately sponsored refugees themselves. Some Vietnamese refugees who were sponsored as young adults in the 1970s now have children and even grandchildren, they share their intergenerational experiences and perspectives of the effect the policy has had in shaping their lives in Canada.

Promotional materials emphasize community strength, growth, and participation in a global community and praise how private sponsorship creates lasting bonds between newcomers and community members, in turn the latter are exposed to broader refugee issues (GRSI, 2016). 
The focus on the community is reinforced by theories of localism and social democracy which allow the model to develop and potentially flourish in the U.K. and Germany. The idea that PSR benefits communities is integral in the promotion and the reception of the model as it sets up in different geopolitical contexts. The positive reinforcement, examples, and case studies that many communities can look towards is important in the global knowledge sharing process about PSR. Indeed, the theme of strengthening communities is one that should be maintained and used to promote the model. It is also important that authentic experiences and testimonials are also portrayed so that the depiction of private sponsorship is well balanced.

\section{Families: first and foremost}

In the GRSI video titled, "How communities sponsor refugees: Canada’s program”, all of the refugee families depicted in the animation consists of a mother wearing a head covering, a father, a child and a baby. Each time a refugee family is shown, it is a variation of this image. In the "Community sponsorship in the U.K." video, the father of the family is interviewed briefly but the main focus is the role of the sponsors, and the sponsored family is in the background. Although nuclear families with young children are not the only people who are privately sponsored, they are most often depicted in the imagery of private sponsorship, if their identities are revealed at all. Like with the Alan Kurdi photo, images of young families are particularly provoking for people to be propelled to help and assist with private sponsorship. However, diverse images of individuals and families that fall outside of this nuclear family structure should be welcomed and utilized to showcase how even more types of people and families are being and can be supported by private sponsorship. In order for the PSR model to grow and develop, I propose that diverse imagery and descriptions of refugee individuals, families, and sponsors, be 
utilized in promotional materials that are used to educate the public about the model and to encourage participation from potential sponsors in a way that is more reflective and representative of the model.

\section{CHAPTER 8}

\section{Conclusion}

In conclusion, this paper has demonstrated that the private sponsorship of the refugees model which originated in Canada is a viable and effective measure of refugee resettlement policy that other countries should implement going forward. The countries chosen for this study have very different cultures and histories in terms of migration and settlement and thus the conversations around immigration and refugees in these contexts are varied. Canada is a settler state, with immigration over the last hundreds of years having significant impact on First Nations peoples and their livelihoods. The U.K. is a former global empire with a history of strict immigration laws on its colonial subjects. Germany is now a dominant political and economic power within the EU. Other models regarding immigration in these countries cannot easily be adapted and exported to Canada because of the stark differences between the identities, histories and cultures of these countries. It is important to determine whether a policy such as private sponsorship, which originated in Canada, can be exported to Germany and the U.K today. In this era of global instability and large population movements, it is important that developed countries like the ones identified in the study work towards a global understanding and effort to alleviate refugee numbers on bordering countries that receive the most refugees, regardless of their histories, identities or policies on immigration. Developing private sponsorship programs in more countries allows for more safe, orderly and legal migration and this is what is necessary on a global level. 
The guiding research question of how, and to what extent, the Canadian model of private sponsorship for refugees has been promoted, received and implemented in Canada, the U.K., and Germany has been viewed through the lens of neoliberalism, localism and social democracy. In Canada, using a neoliberal framework allows us to see how the government has increasingly relied on private sponsorship and civil society over the years to facilitate refugee resettlement. In the U.K., 21st century political leanings towards localism as an ideology for the nation to follow and empower local authorities also encourages community sponsorship to take hold and gain popularity in the country. In Germany, the country's history and use of social democracy is apparent in how their model of private sponsorship has formed and evolved. The U.K. and Germany have utilized Canada as their model in implementing their own PSR programs. Resources available from the GSRI, IRCC and various NGOs have been used as case studies for communities and people in Europe to learn from. Best practices, such as creating a body to administer training and support to sponsorship groups like the creation of Reset in the U.K. which parallels its Canadian counterpart is an example of how resources are formed and adapted to respond to the needs of sponsored refugees and community groups in these places.

There are similarities with the themes, 'ordinary citizens becoming extraordinary', 'community strength', and 'families: first and foremost,' found in the promotional materials of PSR in Canada and in the U.K. These themes highlight expectations, images, and beliefs about private sponsorship and are integral to the model gaining exposure and public support. Potential sponsors or those already interested in issues of refugee resettlement are the primary audience for these promotional materials and not the sponsored refugees themselves. When the PSR model is adopted in the U.K. and Germany, Canada can learn from the different ways that civil society can be involved without having to become a sponsor. Canadian NGOs and government could 
embark on communication and promotion campaigns such as the one Reset in the U.K. has to encourage volunteers to spread the word about private sponsorship (Reset, 2019). Canada could also utilize donation programs for private sponsorship groups like Germany does with the godparent program (Flüchtlingspaten Syrien, 2019).

To sustain the involvement of private actors in private sponsorship of refugee programs, Canada, the U.K. and Germany should continue to facilitate the growth and development of the model provided a number of conditions are met. One, that the number of refugees admitted through PSR should not surpass the numbers of refugees admitted through government sponsorship. Two, effective oversight and evaluation should be administered by governments and NGOs towards groups and communities. Three, diverse images and perspectives of refugees themselves should be used in the promotional material from governments and NGOs about private sponsorship. The PSR model should be supported and promoted as effectively as possible. The goal is to have more legal pathways for refugee resettlement and support many more vulnerable people fleeing conflict or people who remain in bordering countries without a clear path forward in their lives. Private sponsorship has the potential to expand outside Canada and become a global policy, it is already happening, and it should continue. 


\section{BIBLIOGRAPHY}

Adelman, H. (1982). Canada and the Indochinese Refugees. L.A Weigl Educational Associates Ltd. Regina.

Alboim, N. (2016, May 18). Lessons learned from the Indochinese and Syrian refugee movements. Policy Options. Retrieved from: https://policyoptions.irpp.org/magazines/ may-2016/lessons-learned-from-the-indochinese-and-syrian-refugee-movements/

Alfred, C. (2018, April 6). When Refugees Lead: A Conversation with Canada's Refugee Minister. Refugees Deeply. Retrieved from: https://www.newsdeeply.com/refugees/ community/2018/04/06/when-refugees-lead-a-conversation-with-canadas-refugeesminister

Allin, S. (2018, April 24). "New group helping refugees in Haringey". Enfield Independent. Retrieved from: https://www.enfieldindependent.co.uk/news/16181099.new-grouphelping-refugees-in-haringey/

Arat-Koc, S (1999). Neoliberalism, State Restructuring and Immigration: Changes in Canadian Policies in the 1990s. Journal of Canadian Studies, 34(2), 31-56.

Bannerji, H. (2000). The dark side of the nation: Essays on multiculturalism, nationalism and gender. Canadian Scholars' Press. (Introduction, pp. 1-13).

Bathke, B. (2019, May 8). New German resettlement program enlists members of civil society as mentors to help refugees integrate better. Info Migrants. Retrieved from: https://www.infomigrants.net/en/post/16727/new-german-resettlement-program-enlistsmembers-of-civil-society-as-mentors-to-help-refugees-integrate-better

Beale, S. (2019, June 19). How the Left Fell in Love with Localism. The American Conservative. Retrieved from: https://www.theamericanconservative.com/articles/howthe-left-fell-in-love-with-localism/

Beiser, M. (2003). "Sponsorship and resettlement success". Journal of International Migration and Integration, 4(2), 203-215.

Berman, S. (2014). Understanding Social Democracy. Social Democracy Conference. Cambridge, Massachusetts. Harvard University.

Blended Visa-Office Referred Program (2018). Retrieved from: https://www.canada.ca/en/ immigration-refugees-citizenship/services/refugees/help-outside-canada/privatesponsorship-program/blended-visa-office-program.html

Block, K., Warr, D., Gibbs, L., Riggs, E., Addressing Ethical and Methodological Challenges in Research with Refugee-background Young People: Reflections from the Field, Journal of 
Refugee Studies, 26(1): 69-87.

Bloemraad, I. (2013). The promise and pitfalls of comparative research design in the study of migration. Migration Studies, 1(1), 27-46

Bowen, G. (2009). Document Analysis as a Qualitative Research Method. Western Carolina University.

Bundesministerium des Innern, fur Bau und Heimat (2019). Auftaktveranstaltung Pilotgrogramm Neustart im Team (NesT) (2019). Retrieved from: https://www.bmi.bund.de/SharedDocs/ termine/DE/veranstaltungen/M3Neustart/veranstaltung.html;jsessionid=220604CA8BDD CFEA0D3DDD06966F2EFC.2_cid373

Canadian Unitarian Council (2019), A Campaign to Fix Canada's Broken System. Retrieved from: https://cuc.ca/social-justice/refugee-sponsorship/broken-refugee-system/

Casasola, M. (2016). The Indochinese Refugee Movement and the Subsequent Evolution of UNHCR and Canadian Resettlement Selection Policies and Practices. Refuge. 32(2): 4153.

Caulderwood, K. (2015.10.30). Canada's Vietnamese community lends helping hand to Syrian refugees. The Guardian. Retrieved from https://www.theguardian.com/world/2015/oct/30 canada-vietnam-community-syria-refugees

Cheslow, D. (2018, June 6). "Your Children Are Safe: A Town in Wales Welcomes Refugees From Syria". NPR. Retrieved from: https://www.npr.org/2018/06/06/615762704/your -children-Are-safe -a-town-in-wales-welcomes-refugees-from-syria?utm_medium=RSS\& utm_campaign $=$ news\& $\mathrm{t}=1561118021637$

Corbett, S., \& Walker, A. (2019). Between neoliberalism and nationalist populism: What role for the 'European social model' and social quality in post-brexit europe? Social Policy and Society, 18(1), 93-106.

Csillag, R. (May 24, 2017). Politician Ron Atkey opened Canada's doors to boat people. The Globe and Mail. Retrieved from https://www.theglobeandmail.com/news/politics/ politician-ron-atkey-openedcanadas-doors-to-boat-people/article35108399/

D’Addario, S., Hiebert, D., \& Sherrel, K. (2007) Restricted Access: The Role of Social Capital in Mitigating Absolute Homelessness Among Immigrants and Refugees in the GVRD. Refuge: Canada's Journal on Refugees, 24.1: 107-115.

Drei9sziger, N.F., Kovacs, M.L., Body, P., Korvig, B. (1982). Struggle and Hope: The HungarianCanadian Experience. McClelland and Stewart Limited. Toronto.

Easton-Calabria, E., \& Omata, N. (2018). Panacea for the refugee crisis? rethinking the promotion of 'self-reliance' for refugees. Third World Quarterly, 39(8), 1458-1474. 
Erickson, J. (2012). Volunteering with refugees: Neoliberalism, hegemony, and senior citizenship. Human Organization, 71(2), 167-175.

El Chidiac, S. (2018. July 20). The success of the privately sponsored refugee system. Policy Options. https://policyoptions.irpp.org/magazines/july-2018/success-privatelysponsored-refugee-system/

Elements of Ideology: Social Democracy. (n.d). Introduction: What Is Social Democracy. University of Manitoba. Retrieved from: home.cc.umanitoba.ca/ bracken/ socdem.html.

Fekete, L. (2017). Flying the flag for neoliberalism. Race \& Class, 58(3), 3-22.

Feldman, H. (2019, February 16). Where the Countryside Meets the Sea. Sponsor Refugees: Citizens UK Foundation for Community Sponsorship of Refugees. Retrieved from: http://www.sponsorrefugees.org/_where_the_countryside_meets_the_sea

Fenton, R. (2017, October 3). Wanted: One Syrian man to join a Thriving Redbridge Community. Ilford Recorder. Retrieved from: https://www.ilfordrecorder.co.uk/news/ Wanted-one-syrian-family-to-join-a-thriving-redbridge-community

Finotelli, C., \& Kolb, H. (2017). "The good, the bad and the ugly" reconsidered: A comparison of german, canadian and spanish labour migration policies. Journal of Comparative Policy Analysis: Research and Practice, 19(1), 72-86.

Fleischmann, L., \& Steinhilper, E. (2017). The myth of apolitical volunteering for refugees: German welcome culture and a new dispositif of helping. Social Inclusion, 5(3), 17-27.

For Refugees (n.d). Community Sponsorship. Retrieved from: https://forrefugees.uk/communitysponsorship/

Galandini, S., Mulvey, G., \& Lessard-Phillips, L. (2018). Stuck between mainstreaming and Localism: Views on the practice of migrant integration in a devolved policy framework. Journal of International Migration and Integration 1-18.

Global Refugee Sponsorship Initiative (2017). Guidebook and Planning Tools Based on Canada's Model. [PDF File]. Retrieved from: http://refugeesponsorship.org/guidebook

Global Refugee Sponsorship Initiative (2018). GRSI At a Glance: December 2018 Newsletter. [PDF File]. Retrieved from: http://refugeesponsorship.org/_uploads/5c016f8657939.pdf

Global Refugee Sponsorship Initiative (2019). GRSI At a Glance: May 2019 Newsletter. [PDF File]. Retrieved from: http://refugeesponsorship.org/_uploads/5cee995aea654.pdf

Global Refugee Sponsorship Initiative (2019). GRSI At a Glance: June 2019 Newsletter. [PDF File]. Retrieved from: http://refugeesponsorship.org/_uploads/5d167b404d48d.pdf 
Global Refugee Sponsorship Initiative (2018, April 24). How Communities Sponsor Refugees: Canada's Program. [Video File]. Retrieved from: https://www.youtube.com/watch? $\mathrm{v}=\mathrm{KbdXZRbGxz8}$

Global Refugee Sponsorship Initiative (2017, June 6). Sponsorship Experiences-GRSI. [Video File]. Retrieved from: https://www.youtube.com/watch?v=J5pFTgmYYKg

Global Refugee Sponsorship Initiative (2018, June 29) Community Sponsorship in the U.K. [Video File]. Retrieved from: https://www.youtube.com/watch?v=fNGm_ttXf1M

Global Refugee Sponsorship Initiative (n.d) Community Sponsorship. Retrieved from: http://refugeesponsorship.org/community-sponsorship

Godspeed, P. (2014.09.28). Can Canada do for Syrians what it did for boat people?: How a meeting in a Toronto living room ended up changing the lives of 60,000 Vietnamese refugees. Toronto Star.

Gonzalez Benson, O. (2016). Refugee Resettlement Policy in an Era of Neoliberalization: A Policy Discourse Analysis of the Refugee Act of 1980, Social Service Review 90 (3): 515-549.

Government of the United Kingdom (2019, June 17). "New global resettlement scheme for the most vulnerable refugees announced". Retrieved from: https:/www.gov.uk/government /news/new-global-resettlement-scheme-for-the-most-vulnerable-refugees-announced

Government of the United Kingdom. (n.d). Community Sponsorship Scheme. [PDF File]. Retrieved from: https://assets.publishing.service.gov.uk/government/uploads/system/ uploads/attachment_data/file/694792/Community_Sponsorship_Scheme_v4.pdf

Government of the United Kingdom (2018). Community Sponsorship: How you can make it happen (2018). Retrieved from: https://gov.uk/government/publications/communitysponsorship-how-you-can-make-it-happen.

Ha, B \& Tyyskä, V. (2019). Private and Government Sponsorship in the Resettlement Experiences of Chinese-Vietnamese Refugees in Canada. The Promise of MigrationHarris, K. (2016, December 14). 'Extraordinary initiative': Canada's private refugeesponsorship system exported as model for the world. The Canadian Broadcasting Corporation.

Harvey, D. (2007). A brief history of neoliberalism. Retrieved from https://ebookcentralproquest-com.ezproxy.lib.ryerson.ca

Hinger, S. (2016). Asylum in Germany: The Making of the "Crisis" and the Role of Civil 
Society. Human Geography, 9(2), 78-88.

Hinnfors, J., Spehar, A., Bucken-Knapp, G. (2012). The missing factor: Why social democracy can lead to restrictive immigration policy. Journal of European Public Policy, 19(4), 585-603.

Hyndman, J., Payne, W., \& Jimenez, S. (2017). Private refugee sponsorship in Canada. Forced Migration Review, (54), 56-59.

International Catholic Migration Commission (ICMC) Europe (2017). Private Sponsorship in Europe: Expanding Complementary Pathways for Refugee Resettlement.

Immigration, Refugees and Citizenship Canada (2019). Government Assisted Refugees Program Retrieved from: https://www.canada.ca/en/immigration-refugees-citizenship/services refugees/help-outside-canada/government-assisted-refugee-program.html

Immigration, Refugees and Citizenship Canada (2018). Canada welcomes more privately Sponsored refugees in 2018. Retrieved from: https://www.canada.ca/en/immigration-refugees-citizenship/corporate/mandate/ policies-operational-instructions-agreements/timely-protection-privately-sponsored refugees.html

Immigration, Refugees and Citizenship Canada (2019). Guide to the Private Sponsorship of Refugees Program. Retrieved from: https://www.canada.ca/en/immigration-refugees-citizenship/corporate/publicationsmanuals/guide-private-sponsorship-refugees-program.html

International Organization for Migration (2019). The Global Compact for Migration (2019). Retrieved from: https://www.iom.int/global-compact-migration

Ireland, N (September 28, 2016). Canada should talk 'growing pains' with countries looking to Mimic Syrian refugee program, senator says. Canadian Broadcasting Corporation.

Kastning, T. (2013). Basics on Social Democracy. [PDF File]. Friedrich-Ebert-Stiftung-Ghana. Retrieved from:http://www.fesghana.org/index.php?page=what-is-social-democracy

Kelley, N. and Trebilcock, M. (2010). The Making of the Mosaic: A History of Canadian Immigration Policy. University of Toronto Press.

Keyserlingk, R. (1993). Breaking Ground: The 1956 Hungarian Refugee Movement to Canada. York Lanes Press.

Krivenko, E. Y. (2012). Hospitality and sovereignty: What can we learn from the Canadian private sponsorship of refugees program? International Journal of Refugee Law, 24(3), 579-602. 
Kumar Agrawal, S. (2018). Canadian refugee sponsorship programs: Experience of syrian refugees in Alberta, Canada. Journal of International Migration and Integration, 1-22.

Kumin, J. (2015). Welcoming Engagement: How Private Sponsorship Can Strengthen Refugee Resettlement in the European Union. Migration Policy Institute Europe.

Kvale, S. (1995). The Social Construction of Validity. Qualitative Inquiry. 1(1), 19-40.

Labman, S., \& Pearlman, M. (2018). Blending, bargaining, and burden-sharing: Canada's resettlement programs. Journal of International Migration and Integration / Revue De l'Integration Et De La Migration Internationale, 19(2), 439-449.

Labman, S. (2016). Private sponsorship: Complementary or conflicting interests? Refuge, 32(2), 67-80.

Lacroix, P. (2016). From strangers to "humanity first": Canadian social democracy and immigration policy, 1932-1961. Canadian Journal of History, 51(1), 58-82.

Lanphier, M. (2003). Sponsorship: Organizational, sponsor, and refugee perspectives. Journal of International Migration and Integration. 4(2), 237-256.

Lavelle, A. (2008). The death of social democracy: Political consequences in the 21 st century Ashgate Pub. Company.

Lehr, S. (2018, February 26). See a Need and Act on It: Working Group on Resettlement Meetings in Germany. Intercultural Association of Greater Victoria. Retrieved from: http://www.europeanmigrationlaw.eu/documents/Sponsorship-schemes.pdf

Lenard, P. T. (2016). Resettling refugees: Is private sponsorship a just way forward? Journal of Global Ethics, 12(3), 300-310.

Lam, L., Jansen, C., Anisef, P. (2001). A Report on The Settlement Experiences of Kosovar Refugees in Toronto. Centre for Refugee Studies and Joint Centre of Excellence for Research on Immigration and Settlement. York University.

Macklin, A., Barber, K., Goldring, L., Hyndman, J., Korteweg, A., Labman, S., \& Zyfi, J. (2018). A preliminary investigation into private refugee sponsors. Canadian Ethnic Studies, 50(2), 35-57.

McKinlay, C. (2006). Welcoming the stranger: The canadian church and the private sponsorship of refugees program. (Unpublished masters' dissertation). Ryerson University. Toronto, Canada.

Migration Policy Institute Europe (2018). Study on the feasibility and added value of 
sponsorship schemes as a possible pathway to safe channels for admission into the EU, including resettlement. Final Report. Euopean Commission. Retrieved from: http://www. europeanmigrationlaw.eu/documents/Sponsorship-schemes.pdf

Mills, K. (2012). Under the radar: Impact of policies of localism on substance misuse services for refugee and asylum seeking communities. International Social Work, 55(5), 662-674.

Meyer, T., \& Hinchman, L. P. (2007). The theory of social democracy. Bristol: Polity.

Molloy, M. J., \& Simeon, J. C. (2016). "The Indochinese refugee movement and the launch of Canada's private sponsorship program”. Refuge, 32(2).

O’Leary, Z. (2014). The essential guide to doing your research project (2nd ed.). Thousand Oaks, CA: SAGE Publications, Inc.

Phillimore, J. and Reyes, M. (2019). Community Sponsorship in the U.K: From application to integration. Institute for Research into Superdiversity. The University of Birmingham.

Powell, K. (2017). "Brexit positions: Neoliberalism, austerity and immigration-the (im)possibilities? of political revolution." Dialectical Anthropology, 41(3). 225-240.

Porteous, P. (2013). Localism: From adaptive to social leadership. Policy Studies, 34(5-6), 523-540.

Ramos, Howard. 2016. Hosting Refugees: A Decisive Moment for Canada. Canadian Diversity. 13.2: $5-7$.

Ravitch, S. M., \& Riggan, M. (2012). Reason \& rigor: How conceptual frameworks guide Research. Sage Publications.

Reset U.K (2019). Promote. Retrieved from: https://resetuk.org/get-involved/promote

Refugee Sponsorship Training Program (n.d). Overview of Sponsorship Responsibilities (n.d). Retrieved from: http://www.rstp.ca/en/sponsorship-responsibilities/responsibilities/

Ritchie, G. (2018). "Civil society, the state, and private sponsorship: The political economy of Refugee resettlement”. International Journal of Lifelong Education, 37(6), 663-675. doi:10.1080/02601370.2018.1513429

Rolfe, S. (2016). Divergence in community participation policy: Analysing localism and community empowerment using a theory of change approach. Local Government Studies, 42(1), 97-118.

Russel, C. (2005). An Overview of the Integrative Research Review. Progress in Transplantation, 15(1): 8-13. 
Sassoon, D. (1996). One hundred years of socialism: The west european left in the twentieth century. New Press.

Solano, G. \& Savazzi, V. (2019). Private Sponsorship Programmes and humanitarian visas: A viable policy framework for integration? Research Social Platform on Migration and Asylum (ReSOMA).

Schall, C. (2016). The Rise and Fall of the Miraculous Welfare Machine: Immigration and Social Democracy in 20th Century Sweden. Cornell University Press.

Schmidke, O. (2014). Beyond National Models? Governing Migration and Integration at the regional and local levels in Canada and Germany. Comparative Migration Studies, 2(1), 77-99.

Silvius, R. (2016). Neo-liberalization, Devolution, and Refugee Well-Being: A Case Study in Winnipeg, Manitoba. Canadian Ethnic Studies. 48(3), 27-44.

Simich, L. (2003). "Reinforcing refugee resettlement: An introduction to private sponsorship and partnerships." Journal of International Migration and Integration / Revue De l'Integration Et De La Migration Internationale, 4(2), 153-156.

Six Facts About Community Sponsorship (n.d). [PDF File]. Retrieved from: http://refugeesponsorship.org/_uploads/5c0eb9b21f3d9.pdf

Shane, K. (2017, February 8). Exporting a Canadian Success Story. The Hill Times.

Smith, C. Hadziristic, T. \& Alipour, L. (2017, April 4). Private Sponsorship is not a Panacea for Refugee Integration. Refugees Deeply. Retrieved from: https://www.newsdeeply.com/ refugees/community/2017/04/04/private-sponsorship-not-panacea-for-refugeeintegrationresearchers

Soennecken, D. (2014). Shifting Up and Back: The European Turn in Canadian Refugee Policy. Comparative Migration Studies. 2(1): 102-122.

Soteri-Proctor, A., Phillimore, J., \& McCabe, A. (2013). Grassroots civil society at crossroads: Staying on the path to independence or turning onto the UK government's route to localism? Development in Practice, 23(8): 1022-1033.

Statistics Canada (20190. Study: Syrian refugees who resettled in Canada in 2015 and 2016. Retrieved from: https://www150.statcan.gc.ca/n1/daily-quotidien/190212/dq190212a -eng.htm 
Su, R. (2008). A Localist Reading of Local Immigration Regulations. Immigration and Nationality Law Review.

Syrian Refugee Sponsors (2019). Retrieved from: https://fluechtlingspaten-syrien.de/

The Global Refugee Sponsorship Initiative (2018). Retrieved from: https://www.canada.ca/en/immigration-refugeescitizenship/corporate/mandate/corporate -initiatives/global-refugee-sponsorship-initiative.html

The Story of Community Sponsorship in the U.K (2019). Retrieved from: https://www.sponsorrefugees.org/the_story

Thompson, C. (February 13, 2019). Immigration Minister Ahmad Hussen sings praises of private Refugee sponsorship. Windsor Star.

Thompson, M. (2009). The Theory of Social Democracy. Dissent Magazine. (Spring/Summer), 94-101.

Torraco, R. J. (2005). Writing Integrative Literature Reviews: Guidelines and Examples. Human Resource Development Review, 4(3), 356-367.

Tracy, S. (2010) Qualitative quality: Eight "Big-Tent” criteria for excellent qualitative research. Qualitative Inquiry.

Triadafilopoulos, T. (2013). Becoming Multicultural: Immigration and the Politics of Membership in Canada and Germany. UBC Press.

Troper, H. (2003). Becoming an Immigrant City: A History of Immigration in Toronto since the Second World War. In Anisef, P. and Lanphier, M. (eds). The World in a City, Toronto: University of Toronto Press, pp. 19-62.

Turner, E. (2019). Empowering local government or just passing the austerity buck? The changing balance of central and local government in welfare provision in England 2008 -2015. Regional \& Federal Studies, 29(1), 45-65.

Tyyska, V., Blower, J., Deboer, S., Kawai, S., \& Walcott, A. (2018). Canadian media coverage of the Syrian refugee crisis: Representation, response, and resettlement. Geopolitics, History, And International Relations, 10(1), 148-166.

UNHCR. (2016, December 16). Global Refugee Sponsorship Initiative promotes Canada's Private sponsorship model. Retrieved from: https://www.unhcr.org/news/press/ 2016/12/58539e524/global-refugee-sponsorship-initiative-promotes-canadas-privaterefugee.html

Wallace, R. (2018). Contextualizing the crisis: The framing of Syrian refugees in Canadian print 
media. Canadian Journal of Political Science, 51(2), 207-231.

Western University: Centre for Research \& Education on Violence Against Women \& Children (n.d)."What does it mean to be culturally competent?" Retrieved from:

http://rapworkers.com/wp-content/uploads/2017/08/what-does-it-mean-to-be-culturally -competent-1.pdf 